\begin{tabular}{lr}
\hline \multicolumn{1}{c}{ D Y N A M I C E C O N O M E T R I C } & M O D E L S \\
DOI: http://dx.doi.org/10.12775/DEM.2015.003 & Vol. 15 (2015) 49-69 \\
\hline $\begin{array}{l}\text { Submitted September 4, } 2015 \\
\text { Accepted December 15, 2015 }\end{array}$ & ISSN (online) 2450-7067 \\
ISSN (print) 1234-3862
\end{tabular}

\author{
Sabina Nowak, Joanna Olbryś*
}

\title{
Day-of-the-Week Effects in Liquidity on the Warsaw Stock Exchange
}

\begin{abstract}
A b s t r a ct. The purpose of this study is to explore the day-of-the-week patterns in liquidity on the Warsaw Stock Exchange (WSE) using daily turnover as a liquidity measure. The existence of an inverted U-shape in the stock turnover across the trading days is examined. The research sample covers 2502 daily observations in the period January 2005 - December 2014. 53 WSE-listed companies divided into three size groups are investigated. In the study the OLS method with the HAC covariance matrix estimation and the GARCH-type models are employed. The results indicate that liquidity on the WSE tends to be significantly lower on Mondays and higher on Wednesdays in comparison with the other days of the week. However, the inverted U-shape in daily turnover occurs only among the companies with the largest market capitalization.
\end{abstract}

K e y w ord s: market microstructure, day-of-the-week effect, liquidity, turnover, HAC, GARCH, Warsaw Stock Exchange.

J E L Classification: C10, C58, G10, G12.

\section{Introduction}

The day-of-the-week patterns in returns and volatility on stocks and stock market indices rank among the most common seasonality anomalies. There is a growing body of empirical literature on that issue, also for the Polish capital market (see e.g. Fiszeder, 2009 and the references therein). On

\footnotetext{
* Correspondence to: Sabina Nowak, University of Gdansk, Faculty of Management, Armii Krajowej 101, 81-824 Sopot, Poland, e-mail: sabina.nowak@ug.edu.pl; Joanna Olbryś, Bialystok University of Technology, Faculty of Computer Science, e-mail: j.olbrys@pb.edu.pl.
} 
the contrary, relatively little empirical research has been conducted on the day-of-the-week effects in liquidity on equity markets (e.g. Jain, Joh, 1988; Foster, Viswanathan, 1993; Chordia et al., 2001; Chordia et al., 2005; Hameed et al., 2010; Alrabadi, 2012; Karolyi et al., 2012).

The goal of this study is to examine day-of-the-week patterns in liquidity on the Warsaw Stock Exchange (WSE) using daily turnover as a liquidity measure. To address this issue, the OLS method with HAC covariance matrix estimator (Newey, West, 1987) and the GARCH-type models are employed. The research covers the sample period January 2005 - December 2014, during which 53 WSE-listed companies divided into three size groups are investigated. An inverted U-shape in the stock turnover across trading days is examined. This effect means that the trading volume tends to be at its lowest on Monday and Friday, while the most active periods are in the middle of the week (Jain, Joh, 1988).

To the best of the authors' knowledge, the empirical results concerning day-of-the-week effects in liquidity on the WSE are novel and have not been presented in the literature thus far.

The remainder of the study is organized as follows. Section 1 specifies a methodological background and a brief literature review. In Section 2, we present and discuss the empirical results of the day-of-the-week patterns in liquidity on the WSE. Section 3 recalls the main findings and concludes.

\section{Methodological Background}

\subsection{Brief Literature Review}

The presence of calendar anomalies has been investigated extensively since the nineteen seventies. The existence of seasonal behavior in returns and volatility has been widely documented in the finance literature. Some of the fundamental and most broadly citied papers are e.g. (Fama, 1965; French, 1980; Gibbons, Hess, 1981; Rogalski, 1984; French, Roll, 1986, etc). As the aim of this research is to investigate day-of-the-week patterns in liquidity and trading activity, we focus our analysis of previous literature on the studies related mostly to that issue.

Among others, Jain and Joh (1988) studied the trading volume and returns on the New York Stock Exchange (NYSE). They showed significant differences in the trading volume within and across days. The authors provided evidence of an inverted U-shape in volume across days, i.e. Monday and Friday had the lowest volume, and the most active periods were in the middle of the week. 
In their theoretical research, Foster and Viswanathan (1990) proposed a model to explain time-dependent patterns in securities trading. They analysed inter-day trading where an informed trader and a subset of the liquidity traders act strategically. In their model, the informed trader receives information each day, but this information becomes less valuable through time, because there is a public announcement of some portion of the private information. The authors predicted a weekend effect in the trading volume and return volatility. They showed that the trading volume should be lower on Monday than Tuesday, and the trading costs are highest on Monday. In another study, Foster and Viswanathan (1993) introduced empirical tests to document changes in the trading volume within and between days. They tested the null hypothesis that the trading volume is uniform through time. For the interday case, the authors used daily turnover as a measure of trading activity. They found that the Monday trading volume is significantly lower than the Tuesday and Wednesday trading volume for the most actively traded firms. These findings were consistent with the predictions of the FosterViswanathan (1990) theoretical model.

Foerster and Keim (1993) explored the frequency of non-trading for NYSE and AMEX stocks, in the sample period 1973-1990. Among other results, they found an interesting day-of-the-week pattern: non-trading increased monotonically through the week.

Chordia et al. (2001) documented strong day-of-the-week effects in trading activity for the U.S. stock market. They found that Fridays accompanied a significant decrease in trading activity and liquidity, while Tuesdays displayed the opposite pattern. In another paper, Chordia et al. (2005) investigated the U.S. stock and bond markets and they found distinct seasonal patterns in stock and bond liquidities. Both stock and bond market liquidities were higher at the beginning of the week compared with Friday.

Hameed et al. (2010) used bid/ask spread as a measure of liquidity. They regressed the quoted spread of the stocks on a set of variables known to capture seasonal variation in liquidity. The estimated parameters showed calendar effects in the liquidity measure.

Alrabadi (2012) investigated day-of-the-week regularities on the Amman Stock Exchange (ASE). The author confirmed the significant seasonal patterns in aggregate market liquidity on the ASE but, in contrast to the U.S. evidence of Chordia et al. (2001), trading activity reached its minimum in the middle of the week and was significantly higher on Thursdays. Probably, the contradictory results arose from the nature of the ASE as an emerging market. 
Examining commonality in liquidity around the world, Karolyi et al. (2012) followed the approach taken by Hameed et al. (2010) and they measured whether fluctuations in liquidity of individual stocks are correlated within a country. The authors employed the model with day-of-the-week dummies and ran regressions for each stock using two different liquidity measures. The residuals of these regressions were treated as the daily innovations in liquidity and they were subsequently used as the endogenous variables in the monthly regressions. Their coefficients of determination were regarded as the measures of commonality in liquidity of individual stocks.

\subsection{Measuring of Liquidity}

As Lesmond (2005) emphasized, liquidity, by its very nature, is difficult to define and even more difficult to estimate. Given the uncertainty surrounding liquidity estimation, some measures are especially often advocated in the literature to provide empirical research in liquidity/illiquidity effects (e.g. Olbryś, 2014a; 2014b). The popular measures of trading activity, i.e. volume, dollar trading volume, and share or market turnover are among them. The raw trading volume is the number of shares traded. The stock turnover is defined as the ratio of the number of shares traded in a day to the number of shares outstanding at the end of the day. It is worthwhile to note that using turnover disentangles the effect of firm size from the trading volume.

In this research, we compute daily turnover as a measure of liquidity for stock $i$ on day $d$ :

$$
T_{i, d}=\frac{V_{i, d}}{N S O_{i, d}},
$$

where

$T_{i, d}$ is the turnover of stock $i$ on day $d$,

$V_{i, d}$ is the trading volume of stock $i$ on day $d$,

$N S O_{i, d}$ is the number of shares outstanding at the beginning of the quarter for stock $i$ on day $d$.

\subsection{Econometric Analysis of Day-of-the-Week Effects}

Many studies investigating day-of-the-week effects employ the standard OLS methodology by regressing an endogenous variable on daily dummy variables. However, using that methodology has two disadvantages. Firstly, errors in the model may be autocorrelated resulting in misleading inferences. 
Secondly, error variances may not be constant over time (Kiymaz, Berument, 2003). Hamilton (2008) stresses that even if the researcher's primary interest is in estimating the conditional mean, having a correct description of the conditional variance can still be quite important. By incorporating the observed features of the heteroskedasticity into the estimation of the conditional mean, substantially more efficient estimates of the conditional mean can be obtained.

To account for daily seasonality, dummy variables are incorporated into the model. In order to avoid the dummy variable trap (Foster, Viswanathan, 1993), one selected dummy is always excluded from the regression. As the main aim of the research is to examine an inverted U-shape in the stock turnover on the WSE, three different versions of the model are employed. The first version excludes the dummy variable for Monday, the second for Wednesday, and the third for Friday.

Finally, for each stock, daily turnover (1) on day $t$ is composed of a fixed effect for Monday (Wednesday, Friday) $\left(a_{0}\right)$, an inter-day adjustment for days other than Monday (Wednesday, Friday), and an idiosyncratic error term with zero expected value $\left(\varepsilon_{t}\right)$.

The model describing the effect for Monday is given as follows:

$$
T_{t}=a_{0}+\sum_{j=2}^{5} b_{j} d_{j, t}+\varepsilon_{t}
$$

where

$d_{j, t}, j=1,2,3,4,5$ are the dummy variables for Monday $(j=1)$, Tuesday $(\mathrm{j}=2)$, Wednesday $(j=3)$, Thursday $(j=4)$ and Friday $(j=5)$ at time $t$, respectively,

$b_{j}, j=1,2,3,4,5$ are the corresponding coefficients.

The respective models for Wednesday and Friday effects are also considered ${ }^{1}$.

The values of the coefficients of the dummy variables are central to test for inter-day variations in daily turnover. We initially estimate day-of-the-

${ }^{1}$ In the first version of the research in order to address the autocorrelation problem the lagged values of the variable $T_{t}$ were included as the explanatory variables in the model (2). In order to capture a one week delay, the lag equal to 5 was considered. However, employing AR part in formula (2) did not substantially improve the values of the Lagrange Multiplier statistics of the Breusch-Godfrey test for autocorrelation of order 5 - the hypothesis of no autocorrelation was continually rejected. The OLS estimator was therefore inconsistent. 
week effects in Eq. (2) by using the OLS method and the robust HAC estimates $^{2}$. However, the Newey-West corrections may not fully correct for the influence problems introduced by the ARCH effect. For this reason, the estimation of the day-of-the-week effect model as a GARCH-type model is appropriate for this study. To test for the ARCH effect, the test of Engle (1982) with the Lagrange Multiplier (LM) statistic is employed.

In order to test the presence of seasonality anomalies in stock returns, volatility or liquidity, various versions of GARCH-type models (Bollerslev, 1986) have been applied in the literature (e.g. Choudhry, 2000; Franses, Paap, 2000; Berument, Kiymaz, 2001; Kiymaz, Berument, 2003; Apolinario et al., 2006; Žikeš, Bubák, 2006; Alrabadi, 2012). In this research, the $\operatorname{GARCH}(p, q)$ model is utilised. According to the literature, the lower order $\operatorname{GARCH}(\mathrm{p}, \mathrm{q}), p, q=1,2$, models are used in most applications (Tsay, 2010). The GARCH(p, q) models are usually compared and selected by the Akaike (AIC) and Schwarz (SC) information criteria ${ }^{3}$.

The GARCH(p, q) model, with the excluded Monday dummy variable, is given by Eq. (3):

$$
\begin{aligned}
T_{t} & =a_{0}+\sum_{j=2}^{5} b_{j} d_{j, t}+\varepsilon_{t} \\
\varepsilon_{t} & =z_{t} \sqrt{h_{t}}, z_{t} \sim N(0,1), \\
h_{t} & =\alpha_{0}+\sum_{k=1}^{q} \alpha_{k} \cdot \varepsilon_{t-k}^{2}+\sum_{l=1}^{p} \beta_{l} \cdot h_{t-l}, \\
\alpha_{0} & >0, \alpha_{k} \geq 0, k=1, \ldots, q, q>0, \beta_{l} \geq 0, l=1, \ldots, p, p \geq 0,
\end{aligned}
$$

where

$\varepsilon_{t}$ is the innovation in a linear regression with $V(\varepsilon)=\sigma^{2}$,

$h_{t}$ is the variance function,

and remaining notation like in Eq. (2).

Similarly, the $\operatorname{GARCH}(\mathrm{p}, \mathrm{q})$ model with excluded dummy variable for either Wednesday or Friday could be written respectively.

\footnotetext{
${ }^{2} \mathrm{HAC}$ - heteroscedasticity and autocorrelation consistent covariance matrix estimation (Newey, West, 1987).

${ }^{3}$ When the values of the information criteria AIC or SC for different variants of the $\operatorname{GARCH}(p, q)$ models are almost equal, the statistical significance of the parameters in the conditional mean and conditional variance equation of the $\operatorname{GARCH}(\mathrm{p}, \mathrm{q})$ model could be analysed to choose the appropriate model.
} 
The parameters of $\operatorname{GARCH}(\mathrm{p}, \mathrm{q})$ models are almost invariably estimated via Maximum Likelihood (ML) or Quasi-Maximum Likelihood (QML) (Bollerslev, Wooldridge, 1992) methods ${ }^{4}$.

\section{Empirical Results on the Warsaw Stock Exchange}

In this research, a database containing data for the WSE-listed stocks for the period from January 2, 2005 to December 30, 2014 was utilised. When forming the database, we included only those securities which existed on the WSE for the whole sample period since December 31, 2004, and were not suspended. The stock daily trading volumes (in items) were obtained from the website http://www.gpwinfostrefa.pl. The data of the number of shares outstanding are coming from the Notoria Serwis. All companies entered into the database (147) were sorted according to their market capitalization at the end of each year. Next, the stocks were divided into three size groups based on the breakpoints for the bottom 30\% (SMALL - 44 companies), middle 40\% (MEDIUM - 59 companies) and top 30\% (BIG - 44 companies) (e.g. Fama, French, 1993). The companies that remained in the same group during the period investigated were selected. Finally, the 53 WSE companies were entered into separate, representative groups, specifically: 8 firms into the SMALL group, 18 firms into the MEDIUM group and 27 firms into the BIG group (Nowak, Olbryś, 2015). We computed daily turnover $T_{i, d}$ given by Eq. (1), providing 2,502 observations for each company. To avoid numerical problems, the data were rescaled by multiplying by $10^{4}$ (Lucchetti, Balietti, 2014). All calculations were done using Gretl 1.10.1 software (Adkins, 2014).

First we detected stationarity of the analysed daily turnover series for 53 stocks included in the size groups. We employed the ADF-GLS test (Elliott et al., 1996) and we proved that the unit-root hypothesis can be rejected for all series at 5 per cent significance level.

Second, in order to carry out an initial assessment of the existence of an inverted U-shape in the stock turnover on the WSE, the graphs showing the average level of the stock turnover on each day of the week were created. On such basis we noticed the occurrence of an inverted U-shape in the turnover across the majority of the analysed big companies. Their level of turnover turned out to be the lowest on Mondays, increasing on Tuesdays and the

\footnotetext{
${ }^{4}$ To choose the conditional distribution of innovations, various variants of the model (3) were estimated. Unfortunately, they did not yield satisfactory results and even estimation failed in many cases. Therefore, the distribution for the innovations is supposed to be normal.
} 
highest on Wednesdays. However, it subsequently decreased on Thursdays and finally achieved on Fridays the level close to the level of Mondays. It is pertinent to mention that the inverted U-shape in the turnover occurred very rarely for the medium and small companies. In Figure 1, one can observe the average daily turnover of the nine selected big companies, namely BDX, BOS, BPH, KGH, KTY, LPP, NET, OPL, PKN.
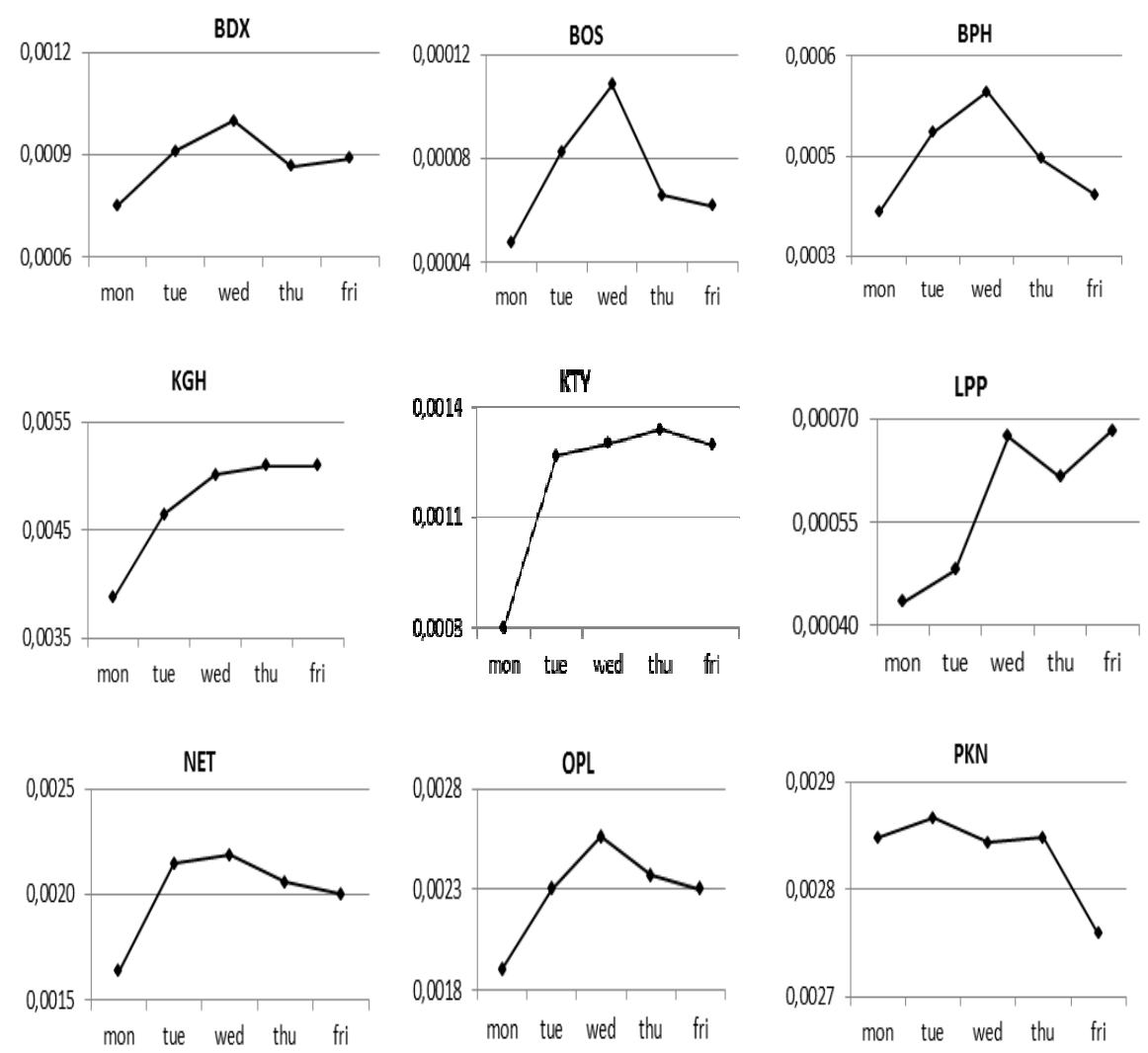

Figure 1. An inverted U-shape in the average daily turnover of selected WSE-stocks

In the next step, we employed the OLS method to estimate the parameters of three versions of the model (2), excluding the dummy variable for Monday, Wednesday and Friday, respectively. In total, 159 models were estimated, comprising 81 models for BIG, 54 for MEDIUM and 24 for SMALL companies. Due to the existence of five order serial autocorrelation 
and - in some cases - also the heteroscedasticity of residuals, the NeweyWest covariance matrix estimator (1987) was employed.

The results of the model (2) estimation with the Monday dummy variable excluded are presented in Tables 2-3 in Appendix ${ }^{5}$. In the case of 35 'without Monday' models (comprising 16 models for big, 11 for medium and 8 for small companies), the ARCH effect in residuals was detected. Therefore, for those 35 companies the GARCH (p, q), $p, q=1,2$, models were estimated. The number of lags $p, q$ was selected on the basis of the Akaike (AIC) and Schwarz (SC) information criteria. The results of the estimation of the 'without Monday' model (3) are reported in Tables 4 -6 in Appendix ${ }^{6}$.

Table 1 presents a brief summary of the major day-of-the-week effects in daily turnover on the WSE.

Table 1. Summarized day-of-the-week effects in daily turnover on the WSE

\begin{tabular}{|c|c|c|c|}
\hline $\begin{array}{l}\text { Effect in daily } \\
\text { turnover }\end{array}$ & BIG group & $\begin{array}{l}\text { MEDIUM } \\
\text { group }\end{array}$ & $\begin{array}{l}\text { SMALL } \\
\text { group }\end{array}$ \\
\hline Monday effect & $\begin{array}{c}\text { BPH, BOS, BDX, BHW, BZW, ECH, GTC, GTN, ING, } \\
\text { KGH, KTY, LPP, MBK, MIL, MOL, NET, OPL, ORB, } \\
\text { PEO, PKN, PKO, SNS, STP, TVN }\end{array}$ & $\begin{array}{l}\text { CNG, MCl, } \\
\text { MNI, STX } \\
\text { VST }\end{array}$ & MZA \\
\hline $\begin{array}{l}\text { Wednesday } \\
\text { effect }\end{array}$ & $\begin{array}{l}\text { BPH, BOS, BDX, BHW, BZW, GTC, GTN, ING, KGH, } \\
\text { KTY, LPP, MBK, MIL, NET, OPL, PEO, PKN, PKO, TVN }\end{array}$ & $\begin{array}{l}\text { MNI, STF } \\
\text { STX }\end{array}$ & MZA \\
\hline $\begin{array}{l}\text { Partial inverted } \\
\text { U-shape }\end{array}$ & $\begin{array}{l}\text { BPH, BOS, BDX, BHW, BZW, GTC, GTN, ING, KGH, } \\
\text { KTY, LPP, MBK, MIL, NET, OPL, PEO, PKN, PKO, TVN }\end{array}$ & MNI, STX & MZA \\
\hline $\begin{array}{l}\text { Full inverted } \\
\text { U-shape }\end{array}$ & $\mathrm{BPH}, \mathrm{ML}$ & - & - \\
\hline \multicolumn{4}{|c|}{$\begin{array}{l}\text { Note: The Monday effect means that the level of daily turnover is statistically significantly lower on } \\
\text { Mondays than on the other days of the week; the Wednesday effect means that the level of daily turnover } \\
\text { is statistically significantly higher on Wednesdays in comparison with Mondays and/or the other days of } \\
\text { the week; the partial inverted U-shape in turnover means the presence of the Monday and Wednesday } \\
\text { effects, but the absence of the Friday effect; the full inverted U-shape in turnover means the presence of } \\
\text { the Monday, Wednesday and Friday effects at the same time. }\end{array}$} \\
\hline
\end{tabular}

The obtained estimation results of the models (2) and (3) led to the conclusion that the 'Monday effect' was the most frequently present in the stock turnover time series. In the case of 24 big and 3 medium firms, the level of daily turnover was statistically significantly lower on Mondays than on the other days of the week ${ }^{7}$. The 'Wednesday effect' (recognized in those cases when the level of daily turnover was statistically significantly higher on

\footnotetext{
${ }^{5}$ The estimation results of the models with Wednesday and Friday dummies excluded are available upon request.

${ }^{6}$ See footnote 3 .

${ }^{7}$ At the 5 per cent level.
} 
Wednesdays in comparison with Mondays and/or the other days of the week) occurred in the case of 19 big companies. The findings of the 'Friday effect' existence were ambiguous.

The results mentioned above justify the preliminary conclusions from analysing the graphs, where a pronounced 'Monday effect' accompanied by a weaker 'Wednesday effect' were detected. Besides, both effects occurred more often in the case of big companies.

Continuing the analysis of the model (2) estimation results, we observed the presence of the so-called 'partial inverted U-shape' in daily turnover related to the presence of the Monday and Wednesday effect, but not the Friday effect, in the case of 19 out of 27 big firms (namely BPH, BOS, BDX, BHW, BZW, GTC, GTN, ING, KGH, KTY, LPP, MBK, MIL, NET, OPL, PEO, PKN, PKO, TVN). For these companies, the level of daily turnover turned out to be either statistically significantly lower on Mondays than on Wednesdays and/or the other days of the week, or statistically significantly higher on Wednesdays than on Mondays. Moreover, on the basis of the model (3) estimation, we found the 'partial inverted U-shape' in daily turnover for 14 companies, including 11 big (BPH, GTC, ING, KGH, MBK, MIL, NET, OPL, PEO, PKN, PKO), 2 medium (MNI, STX) and 1 small firm (MZA).

Furthermore, we did not confirm the occurrence of the "full inverted U-shape' in daily turnover of the companies analysed, since in the majority of the cases the level on Friday turnover was not statistically significantly lower than on the other days of the week. For 17 big companies (BHW, BZW, ECH, GTC, GTN, ING, KGH, KTY, LPP, MBK, MIL, NET, OPL, PEO, PKN, PKO, TVN) the level of turnover on Fridays was statistically significantly higher compared with the level on Mondays. Only for 2 big companies (BPH and OPL) the daily turnover level turned out to be statistically significantly lower on Fridays in comparison with Wednesdays.

Barely for 2 companies (BPH and MIL) we can venture the conclusion of the existence of the 'full inverted U-shape' in daily turnover (involving Monday, Wednesday and Friday effect at the same time). In the case of the BPH company, on the basis of the model (2) estimation, we noted that the turnover was simultaneously: (i) statistically significantly lower on Mondays compared with Tuesdays, Wednesdays and Thursdays; (ii) statistically significantly higher on Wednesdays compared with Mondays, Thursdays and Fridays; (iii) statistically significantly lower on Fridays compared with Tuesdays and Wednesdays. Those findings were only partially confirmed by the results of the estimation of the model (3), which showed rather the existence of the 'partial inverted U-shape' in daily turnover of the BPH. Con- 
versely, in the case of the MIL company, the results of the model (2) estimation proved the occurrence of the 'partial inverted U-shape', whereas the results of model (3) estimation - the existence of the 'full inverted U-shape' in the stock turnover.

\section{Conclusions}

The main goal of this paper was to explore and to document day-of-theweek effects in liquidity on the WSE, using daily turnover as a liquidity measure. To address this issue, we employed the OLS method with the HAC covariance matrix estimation and the GARCH-type models. To account for daily seasonality in the turnover, dummy variables were incorporated into the models. We investigated 53 WSE-listed stocks from three size groups. Our research provided evidence for pronounced Monday and Wednesday effects in daily turnover on the WSE, especially in the BIG group. Furthermore, we observed the so-called 'partial inverted U-shape' in daily turnover in the case of 22 out of 53 firms. Moreover, the graphs showing the average daily stock turnover on each day of the week were created and they revealed an inverted U-shape in some cases.

Although relatively little empirical research has been conducted on the day-of-the-week effects in liquidity on stock markets in the world, our findings are rather consistent with the existing literature. In light of our empirical results, it seems that the trading volume on the WSE is usually the lowest on Mondays, but the most active periods are in the middle of the week. From an investor's point of view it is important that these findings are also in accordance with the investor's intuition.

It is worth stressing that our study situates itself in the broad strand of literature concerning commonality in liquidity, which is nowadays the centre of attention of many empirical research papers (e.g. Olbryś, 2014a; 2014b; Karolyi et al., 2012). Given the importance of the topic, one of the possible directions for further investigation could be to examine day-of-the-week patterns in liquidity on the WSE following the methodology proposed by Franses and Paap (2000) or Žikeš and Bubák (2006). The former authors employ the PAR-PGARCH model to investigate the seasonality in the S\&P 500 index, while the latter use the same model to explore daily returns on the Central European stock markets. 


\section{References}

Adkins, L. C. (2014), Using Gretl for Principles of Econometrics, 4th Edition, Version 1.041. Alrabadi, D. W. H. (2012), An Analysis of Aggregate Market Liquidity: The Case of Amman Stock Exchange, International Business Research, 5(5), 184-194, DOI: http://dx.doi.org/10.5539/ibr.v5n5p184.

Apolinario, R. M. C, Santana, O. M., Sales, L. J. (2006), Day of the Week Effect on European Stock Markets, International Research Journal of Finance and Economics, 2, 53-70.

Berument, H., Kiymaz, H. (2001), The Day of the Week Effect on Stock Market Volatility, Journal of Economics and Finance, 25(2), 181-193, DOI: http://10.1016/S1058-3300(03)00038-7.

Bollerslev, T. (1986), Generalized Autoregressive Conditional Heteroskedasticity, Journal of Econometrics, 31, 307-327, DOI: http://10.1016/0304-4076(86)90063-1.

Bollerslev, T., Wooldridge, J. M. (1992), Quasi-Maximum Likelihood Estimation and Inference in Dynamic Models with Time-Varying Covariances, Econometric Reviews, 11, 143-179, DOI: http://10.1080/07474939208800229.

Chordia, T., Roll, R., Subrahmanyam, A. (2001), Market Liquidity and Trading Activity, Journal of Finance, 56(2), 501-530, DOI: http://10.1111/0022-1082.00335.

Chordia, T., Sarkar, A., Subrahmanyam, A. (2005), An Empirical Analysis of Stock and Bond Market Liquidity, Review of Financial Studies, 18(1), 85-129, DOI: http://10.1093/rfs/hhi010.

Choudhry, T. (2000), Day of the week Effect in Emerging Asian Stock Markets: Evidence from the GARCH Model, Applied Financial Economics, 10, 235-242, DOI: http://10.1080/096031000331653.

Elliott, G., Rothenberg, T. J., Stock, J. H. (1996), Efficient Tests for an Autoregressive Unit Root, Econometrica, 64(4), 813-836, DOI: http://dx.doi.org/10.2307/2171846.

Engle, R. F. (1982), Autoregressive Conditional Heteroscedasticity with Estimates of the Variance of United Kingdom Inflations, Econometrica, 50, 987-1007,

DOI: http://dx.doi.org/10.2307/1912773.

Fama, E. F. (1965), The Behaviour of Stock Market Prices, Journal of Business, 38, 34-105.

Fama, E. F., French, K.R. (1993), Common Risk Factors in the Returns on Stocks and Bonds, Journal of Financial Economics, 33(1), 3-56.

Fiszeder, P. (2009), Modele klasy GARCH w empirycznych badaniach finansowych (The Class of GARCH Models in Empirical Finance Research), Nicolaus Copernicus University Press, Torun.

Foerster, S., Keim, D. (1993), Direct Evidence of Non-Trading of NYSE and AMEX Stocks, Working Paper, University of Pennsylvania.

Foster, F. D., Viswanathan, S. (1990), A Theory of the Interday Variations in Volume, Variances, and Trading Cost in Securities Market, Review of Financial Studies, 3(4), 593-624, DOI: http://dx.doi.org/10.1093/rfs/3.4.593.

Foster, F. D., Viswanathan, S. (1993), Variations in Trading Volume, Return Volatility, and Trading Costs: Evidence on Recent Price Formation Models, Journal of Finance, 48(1), 187-211, DOI: http://dx.doi.org/10.2307/2328886.

Franses, P. H., Paap, R. (2000), Modelling Day-of-the-Week Seasonality in the S\&P 500 Index, Applied Financial Economics, 10, 483-488, DOI: http://dx.doi.org/10.1080/096031000416352.

French, K. R. (1980), Stock Returns and the Weekend Effect, Journal of Financial Economics, 8, 55-69, DOI: http://dx.doi.org/10.1016/0304-405X(80)90021-5. 
French, K. R., Roll, R. (1986), Stock Returns Variances: The Arrival of Information of the Reaction of Traders, Journal of Financial Economics, 17, 5-26.

Gibbons, M., Hess, P. (1981), Day of the Week Effects and Asset Returns, Journal of Business, 54, 579-596, DOI: http://dx.doi.org/10.1086/296147.

Hameed, A., Kang, W., Viswanathan, S. (2010), Stock Market Declines and Liquidity, Journal of Finance, 65(1), 257-293, DOI: http://dx.doi.org/10.1111/j.1540-6261.2009.01529.x.

Hamilton, J. D. (2008), Macroeconomics and ARCH, Working Paper 14151, NBER Working Paper Series, Cambridge.

Jain, P. C., Joh, G.-H. (1988), The Dependence between Hourly Prices and Trading Volume, Journal of Financial and Quantitative Analysis, 23(3), 269-284.

Karolyi, G. A., Lee, K.-H., van Dijk, M. A. (2012), Understanding Commonality in Liquidity Around the World, Journal of Financial Economics, 105(1), 82-112, DOI http://dx.doi.org/10.1016/j.jfineco.2011.12.008.

Kiymaz, H., Berument, H. (2003), The Day of the Week Effect on Stock Market Volatility and Volume: International Evidence, Review of Financial Economics, 12(4), 363-380, DOI: http://dx.doi.org/10.1016/S1058-3300(03)00038-7.

Lesmond, D. A. (2005), Liquidity of Emerging Markets, Journal of Financial Economics, 77(2), 411 -452, DOI: http://dx.doi.org/10.1016/j.jfineco.2004.01.005.

Lucchetti, J., Balietti, S. (2014), The gig Package, Version 2.14.

Newey, W. K., West, K. D. (1987), A Simple, Positive Semi-Define, Heteroskesticity and Autocorrelation Consistent Covariance Matrix, Econometrica, 55(3), 703-708, DOI: http://dx.doi.org/10.2307/1913610.

Nowak, S., Olbryś, J. (2015), Autokorelacja stóp zwrotu spółek giełdowych w kontekście zakłóceń w procesach transakcyjnych (Serial Correlation of Individual Stock Returns in the Context of Friction in Trading Processes), Zeszyty Naukowe Uniwersytetu Szczecińskiego No. 854. Finanse, Rynki Finansowe, Ubezpieczenia, 73, 721 -734.

Olbryś, J. (2014a), Is Illiquidity Risk Priced? The Case of the Polish Medium-Size Emerging Stock Market, Bank i Kredyt, 45(6), 513-536.

Olbryś, J. (2014b), Wycena aktywów kapitałowych na rynku z zakłóceniami w procesach transakcyjnych (Capital Asset Pricing on Market with Frictions in Trading Processes), Difin Press, Warszawa.

Rogalski, R. J. (1984), New Findings Regatding Day-of-the-Week Returns Over Trading and Nontrading Periods: A Note, Journal of Finance, 35, 1603-1614.

Tsay, R. S. (2010), Analysis of Financial Time Series, John Wiley, New York.

Žikeš, F., Bubák, V. (2006), Seasonality and the Non-Trading Effect on Central European Stock Markets, Czech Journal of Economics and Finance, 56, 69-79.

\section{Analiza efektu dnia tygodnia w płynności spółek notowanych na Giełdzie Papierów Wartościowych w Warszawie S.A.}

$\mathrm{Z}$ a r y s t r e ś c i. Celem artykułu jest analiza występowania efektu dnia tygodnia w płynności spółek notowanych na Giełdzie Papierów Wartościowych w Warszawie S.A., z wykorzystaniem dziennych wartości względnego wolumenu jako miary płynności. Badaniu poddano w szczególności występowanie tzw. efektu odwróconego U w dziennym względnym wolumenie 53 spółek, z podziałem na grupy według wartości rynkowej, w okresie od stycznia 2005 r. do grudnia 2014 r. W badaniu wykorzystano modele OLS-HAC oraz GARCH. Na 
podstawie uzyskanych wyników stwierdzono, że dzienny względny wolumen na giełdzie warszawskiej jest generalnie istotnie niższy w poniedziałki (tzw. efekt poniedziałku) oraz istotnie wyższy w środy (tzw. efekt środy) w porównaniu do pozostałych dni tygodnia. Ponadto zaobserwowano, że częściowy efekt odwróconego U występuje głównie w dziennym względnym wolumenie spółek o największej kapitalizacji. Efekt ten oznacza jednoczesną obecność efektów poniedziałku i środy, przy braku tzw. efektu piątku, czyli spadku dziennego względnego wolumenu w piątek do poziomu z początku tygodnia.

S łow a kluczowe: mikrostruktura rynku, efekt dnia tygodnia, płynność, względny wolumen, HAC, GARCH, Giełda Papierów Wartościowych w Warszawie S.A.

Dynamic Econometric Models 15 (2015) 49-69 


\section{Appendix}

Table 2. Estimation results of model (2), OLS-HAC, Monday dummy variable excluded, the BIG group

\begin{tabular}{|c|c|c|c|c|c|c|c|c|c|c|c|c|c|c|}
\hline \multicolumn{15}{|c|}{ BIG group } \\
\hline & BPH & BNP & BOS & BDX & BZW & DBC & $\mathrm{ECH}$ & GTN & GTC & $\mathrm{BHW}$ & ING & KTY & KGH & LPP \\
\hline$b_{2}$ & $1.196^{* \star *}$ & 0.093 & $0.346^{* *}$ & 1.590 & $1.850^{* * *}$ & 0.977 & $1.657^{\star * *}$ & $2.052^{\star * *}$ & $2.432^{\star * *}$ & $1.406^{*}$ & $0.152^{*}$ & $4.653^{\star * *}$ & $7.685^{\star * *}$ & 0.470 \\
\hline$b_{3}$ & $1.802^{* * *}$ & -0.010 & $0.606^{* *}$ & $2.466^{* *}$ & $2.176^{\star * \star}$ & $1.270^{*}$ & $0.755^{\star}$ & $3.415^{\star \star *}$ & $4.006^{\star * *}$ & $1.306^{* *}$ & $0.372^{\star *}$ & $4.991^{\star * *}$ & $11.346^{* \star *}$ & $2.403^{* * *}$ \\
\hline$b_{4}$ & $0.804^{\star *}$ & -0.042 & 0.179 & 1.147 & $1.512^{\star *}$ & $1.589^{*}$ & $1.255^{\star \star \star}$ & $2.767^{\star \star \star}$ & $5.197^{\star \star *}$ & 0.578 & $0.283^{* *}$ & $5.359^{* \star *}$ & $12.181^{* * *}$ & $1.809^{* *}$ \\
\hline$b_{5}$ & 0.265 & -0.012 & 0.139 & 1.376 & $2.476^{\star * *}$ & 1.190 & $1.448^{* * *}$ & $4.077^{\star * *}$ & $4.390^{* * *}$ & $1.387^{* *}$ & $0.184^{* *}$ & $4.926^{* * *}$ & $12.150^{* * *}$ & $2.483^{* *}$ \\
\hline LM & $\begin{array}{l}47.640 \\
{[0.000]}\end{array}$ & $\begin{array}{l}874.406 \\
{[0.000]}\end{array}$ & $\begin{array}{c}3.037 \\
{[0.694]}\end{array}$ & $\begin{array}{l}11.683 \\
{[0.039]}\end{array}$ & $\begin{array}{c}5.826 \\
{[0.324]}\end{array}$ & $\begin{array}{c}0.489 \\
{[0.993]}\end{array}$ & $\begin{array}{c}4.562 \\
{[0.472]}\end{array}$ & $\begin{array}{c}240.258 \\
{[0.000]}\end{array}$ & $\begin{array}{l}13.985 \\
{[0.016]}\end{array}$ & $\begin{array}{l}11.028 \\
{[0.051]}\end{array}$ & $\begin{array}{l}23.055 \\
{[0.000]}\end{array}$ & $\begin{array}{c}0.051 \\
{[0.999]}\end{array}$ & $\begin{array}{c}279.072 \\
{[0.000]}\end{array}$ & $\begin{array}{c}0.748 \\
{[0.980]}\end{array}$ \\
\hline$T R^{2}$ & $\begin{array}{c}605.480 \\
{[0.000]}\end{array}$ & $\begin{array}{l}606.167 \\
{[0.000]}\end{array}$ & $\begin{array}{c}248.992 \\
{[0.000]}\end{array}$ & $\begin{array}{l}198.401 \\
{[0.000]}\end{array}$ & $\begin{array}{l}580.037 \\
{[0.000]}\end{array}$ & $\begin{array}{l}128.216 \\
{[0.000]}\end{array}$ & $\begin{array}{c}231.766 \\
{[0.000]}\end{array}$ & $\begin{array}{l}764.311 \\
{[0.000]}\end{array}$ & $\begin{array}{l}589.677 \\
{[0.000]}\end{array}$ & $\begin{array}{c}206.991 \\
{[0.000]}\end{array}$ & $\begin{array}{l}391.061 \\
{[0.000]}\end{array}$ & $\begin{array}{l}108.312 \\
{[0.000]}\end{array}$ & $\begin{array}{l}661.087 \\
{[0.000]}\end{array}$ & $\begin{array}{l}85.203 \\
{[0.000]}\end{array}$ \\
\hline$W$ & $\begin{array}{l}13.352 \\
{[0.010]}\end{array}$ & $\begin{array}{c}2.752 \\
{[0.600]}\end{array}$ & $\begin{array}{c}5.947 \\
{[0.203]}\end{array}$ & $\begin{array}{c}3.715 \\
{[0.446]}\end{array}$ & $\begin{array}{c}5.378 \\
{[0.251]}\end{array}$ & $\begin{array}{c}3.969 \\
{[0.410]}\end{array}$ & $\begin{array}{c}6.425 \\
{[0.170]}\end{array}$ & $\begin{array}{c}6.298 \\
{[0.178]}\end{array}$ & $\begin{array}{c}4.444 \\
{[0.349]}\end{array}$ & $\begin{array}{c}2.386 \\
{[0.665]}\end{array}$ & $\begin{array}{c}3.189 \\
{[0.527]}\end{array}$ & $\begin{array}{c}4.435 \\
{[0.350]}\end{array}$ & $\begin{array}{c}5.903 \\
{[0.207]}\end{array}$ & $\begin{array}{c}5.023 \\
{[0.285]}\end{array}$ \\
\hline
\end{tabular}


Table 2 cont. Estimation results of model (2), OLS-HAC, Monday dummy variable excluded, the BIG group

\begin{tabular}{cccccccccccccc}
\hline & \multicolumn{10}{c}{ BIG group } \\
\hline & MBK & ML & MOL & NET & ORB & PEO & PKN & PKO & STP & SNS & OPL & TVN & ZWC \\
\hline$b_{2}$ & $1.664^{* * *}$ & $1.979^{* * *}$ & 0.034 & $5.087^{* * *}$ & 0.409 & $3.884^{* * *}$ & $4.587^{* * *}$ & $3.230^{* * *}$ & 0.553 & $1.529^{* *}$ & $3.973^{* * *}$ & $1.993^{* * *}$ & 0.033 \\
$b_{3}$ & $2.834^{* * *}$ & $2.565^{* * *}$ & $0.101^{*}$ & $5.478^{* * *}$ & 1.248 & $4.791^{* * *}$ & $6.311^{* * *}$ & $5.246^{* * *}$ & 0.420 & $0.824^{*}$ & $6.573^{* * *}$ & $2.052^{* * *}$ & 0.013 \\
$b_{4}$ & $2.181^{* * *}$ & $2.762^{* * *}$ & $0.197^{* * *}$ & $4.224^{* * *}$ & $2.971^{* *}$ & $4.651^{* * *}$ & $7.472^{* * *}$ & $5.610^{* * *}$ & $1.000^{* *}$ & 0.214 & $4.668^{* * *}$ & $2.001^{* * *}$ & 0.000 \\
$b_{5}$ & $2.308^{* * *}$ & $2.018^{* * *}$ & $0.168^{*}$ & $3.644^{* * *}$ & 1.683 & $4.363^{* * *}$ & $7.437^{* * *}$ & $5.262^{* * *}$ & 0.271 & 3.078 & $3.967^{* * *}$ & $4.161^{* * *}$ & 0.009 \\
\hline LM & 184.953 & 33.166 & 3.164 & 16.050 & 2.372 & 542.272 & 74.756 & 471.023 & 16.104 & 0.008 & 36.749 & 0.851 & 195.769 \\
& {$[0.000]$} & {$[0.000]$} & {$[0.675]$} & {$[0.007]$} & {$[0.796]$} & {$[0.000]$} & {$[0.000]$} & {$[0.000]$} & {$[0.007]$} & {$[1.000]$} & {$[0.000]$} & {$[0.974]$} & {$[0.000]$} \\
$T R^{2}$ & 727.798 & 277.598 & 298.113 & 537.436 & 46.544 & 616.530 & 580.538 & 922.911 & 147.017 & 79.600 & 390.676 & 484.002 & 461.129 \\
& {$[0.000]$} & {$[0.000]$} & {$[0.000]$} & {$[0.000]$} & {$[0.000]$} & {$[0.000]$} & {$[0.000]$} & {$[0.000]$} & {$[0.000]$} & {$[0.000]$} & {$[0.000]$} & {$[0.000]$} & {$[0.000]$} \\
$W$ & 9.385 & 5.842 & 6.865 & 4.434 & 3.801 & 5.465 & 14.533 & 9.897 & 2.515 & 4.168 & 3.358 & 5.732 & 2.572 \\
& {$[0.052]$} & {$[0.211]$} & {$[0.143]$} & {$[0.350]$} & {$[0.434]$} & {$[0.243]$} & {$[0.006]$} & {$[0.042]$} & {$[0.642]$} & {$[0.384]$} & {$[0.500]$} & {$[0.220]$} & {$[0.632]$} \\
\hline
\end{tabular}

Note: $b_{2}, b_{3}, b_{4}, b_{5}$ - the estimates of the model (2) coefficients using the OLS method with the HAC covariance matrix estimator (Newey, West, 1987); ** $(* * *, *)$ - indicates statistical significance at 5 per cent (1 per cent, 10 per cent) significance level; $L M$ - the Lagrange Multiplier statistic of the Engle's test (1982), order lag equal to $5 ; \bar{R}^{2}$ - the adjusted $R^{2}, T R^{2}$ - the Lagrange Multiplier statistic of the Breusch-Godfrey test for autocorrelation of order $5 ; W-$ the White statistic; relevant p-values in brackets under the estimates. 
Table 3. Estimation results of model (2), OLS-HAC, Monday dummy variable excluded, the MEDIUM group

\begin{tabular}{ccccccccccccccc}
\hline & \multicolumn{10}{c}{ MEDIUM group } \\
\hline & ALM & AMC & ATM & ATG & COL & IPL & IND & LTX & MCl & MNI & CNG & PEK & SKA & STX \\
\hline$b_{2}$ & 0.683 & -0.161 & -0.038 & 0.787 & 0.310 & -0.030 & 1.632 & 0.237 & $4.375^{* *}$ & 0.949 & $3.768^{* *}$ & 0.191 & $2.644^{*}$ & 0.003 \\
$b_{3}$ & 1.331 & 0.199 & 0.124 & 0.144 & 0.024 & 1.688 & 0.684 & -0.348 & $4.873^{*}$ & 4.299 & $3.331^{*}$ & 1.162 & 0.689 & 0.301 \\
$b_{4}$ & 0.128 & 1.252 & 1.229 & -0.098 & 0.272 & 1.647 & $2.898^{*}$ & -1.140 & $7.143^{* *}$ & 3.708 & $4.117^{* *}$ & 1.011 & $1.906^{*}$ & 1.630 \\
$b_{5}$ & 0.672 & 0.379 & -0.456 & 1.016 & 0.758 & 1.191 & 0.720 & -1.106 & 2.718 & 2.797 & $2.487^{*}$ & 0.353 & 1.138 & 0.978 \\
\hline LM & 21.847 & 67.675 & 41.616 & 1.936 & 84.352 & 4.026 & 4.568 & 569.325 & 501.096 & 438.636 & 7.008 & 38.001 & 4.068 & 692.530 \\
& {$[0.001]$} & {$[0.000]$} & {$[0.000]$} & {$[0.858]$} & {$[0.000]$} & {$[0.546]$} & {$[0.471]$} & {$[0.000]$} & {$[0.000]$} & {$[0.000]$} & {$[0.220]$} & {$[0.000]$} & {$[0.540]$} & {$[0.000]$} \\
$T R^{2}$ & 298.859 & 551.466 & 205.035 & 293.065 & 664.712 & 305.668 & 107.632 & 1245.440 & 1175.298 & 964.227 & 269.080 & 314.258 & 52.412 & 1189.473 \\
& {$[0.000]$} & {$[0.000]$} & {$[0.000]$} & {$[0.000]$} & {$[0.000]$} & {$[0.000]$} & {$[0.000]$} & {$[0.000]$} & {$[0.000]$} & {$[0.000]$} & {$[0.000]$} & {$[0.000]$} & {$[0.000]$} & {$[0.000]$} \\
$W$ & 2.351 & 0.975 & 2.566 & 2.921 & 3.700 & 3.811 & 6.533 & 0.903 & 2.354 & 1.316 & 3.668 & 2.186 & 5.264 & 1.610 \\
& {$[0.671]$} & {$[0.914]$} & {$[0.633]$} & {$[0.571]$} & {$[0.448]$} & {$[0.432]$} & {$[0.163]$} & {$[0.924]$} & {$[0.671]$} & {$[0.859]$} & {$[0.453]$} & {$[0.702]$} & {$[0.261]$} & {$[0.807]$} \\
\hline
\end{tabular}


Table 3 cont. Estimation results of model (2), OLS-HAC, Monday dummy variable excluded, the MEDIUM and SMALL groups

\begin{tabular}{ccccc|cccccccc}
\hline \multicolumn{10}{c}{ MEDIUM group } \\
\hline & STF & TIM & VST & PUE & APL & BDL & EFK & ENP & KMP & MZA & PLA & SME \\
\hline$b_{2}$ & $2.262^{*}$ & 1.997 & $4.450^{* *}$ & 1.426 & 17.500 & -0.062 & $3.036^{*}$ & -3.250 & 1.984 & $8.368^{*}$ & -8.366 & -0.459 \\
$b_{3}$ & -0.382 & $1.979^{*}$ & 2.782 & $3.657^{*}$ & 12.106 & 0.176 & 1.021 & 6.769 & 1.071 & 12.335 & -3.698 & 0.978 \\
$b_{4}$ & 0.718 & 2.126 & 5.249 & 3.567 & 9.275 & 0.033 & 2.840 & -3.308 & -2.865 & 11.356 & -5.348 & 0.985 \\
$b_{5}$ & -1.033 & 0.104 & 0.689 & 1.011 & -2.722 & 0.269 & 2.103 & -2.614 & $-7.695^{*}$ & 5.771 & -1.797 & -0.155 \\
\hline LM & 426.069 & 0.153 & 613.836 & 0.173 & 279.249 & 1245.050 & 1029.52 & 380.345 & 665.594 & 619.648 & 565.978 & 929.439 \\
& {$[0.000]$} & {$[0.999]$} & {$[0.000]$} & {$[0.999]$} & {$[0.000]$} & {$[0.000]$} & {$[0.000]$} & {$[0.000]$} & {$[0.000]$} & {$[0.000]$} & {$[0.000]$} & {$[0.000]$} \\
$T R^{2}$ & 777.058 & 58.392 & 1106.698 & 34.729 & 987.168 & 1159.090 & 1095.110 & 1135.479 & 1153.429 & 1224.741 & 1196.819 & 1370.149 \\
& {$[0.000]$} & {$[0.000]$} & {$[0.000]$} & {$[0.000]$} & {$[0.000]$} & {$[0.000]$} & {$[0.000]$} & {$[0.000]$} & {$[0.000]$} & {$[0.000]$} & {$[0.000]$} & {$[0.000]$} \\
$W$ & 3.111 & 3.244 & 3.694 & 2.987 & 4.153 & 1.408 & 1.450 & 1.977 & 3.193 & 3.555 & 3.043 & 0.498 \\
& {$[0.539]$} & {$[0.518]$} & {$[0.449]$} & {$[0.560]$} & {$[0.386]$} & {$[0.843]$} & {$[0.835]$} & {$[0.740]$} & {$[0.526]$} & {$[0.470]$} & {$[0.551]$} & {$[0.974]$} \\
\hline
\end{tabular}

Note: See Table 2 for explanation. 
Table 4. Estimation results of model (3), GARCH(p, q), Monday dummy variable excluded, the BIG group

\begin{tabular}{|c|c|c|c|c|c|c|c|c|c|c|c|c|c|c|c|}
\hline \multicolumn{16}{|c|}{ BIG group } \\
\hline & BPH & BDX & GTN & GTC & ING & $\mathrm{KGH}$ & MBK & MIL & NET & PEO & PKN & PKO & STP & OPL & ZWC \\
\hline \multicolumn{16}{|c|}{ Conditional mean equation } \\
\hline$b_{2}$ & 0.81 & $5.61^{* *}$ & $1.19^{*}$ & 1.84 & 0.11 & $6.05^{\star \star *}$ & 0.88 & $1.73^{\star \star}$ & 1.88 & $3.60^{* * *}$ & $4.10^{\star * *}$ & $2.53^{* * *}$ & 0.81 & $5.86^{\star * *}$ & $0.07^{* * *}$ \\
\hline$b_{3}$ & $1.30^{* *}$ & 1.83 & $2.06^{* * *}$ & $3.70^{\star * *}$ & $0.26^{* * *}$ & $10.30^{\star * *}$ & $1.85^{\star \star *}$ & $6.67^{* \star *}$ & $8.38^{\star * *}$ & $4.20^{* * *}$ & $5.77^{\star * *}$ & $3.97^{* * *}$ & -0.16 & $5.80^{* * *}$ & $0.02^{* *}$ \\
\hline$b_{4}$ & $1.46^{* *}$ & 3.65 & 1.11 & $2.99^{* * *}$ & 0.15 & $11.73^{\star \star *}$ & $2.50^{\star *}$ & -0.85 & $6.53^{* \star *}$ & $3.61^{* * *}$ & $6.77^{* * *}$ & $4.17^{\star * *}$ & 0.26 & $5.04^{* * *}$ & 0.01 \\
\hline$b_{5}$ & 2.59 & -0.55 & $2.83^{* * *}$ & 3.57 & $0.16^{* *}$ & $10.31^{* * *}$ & $2.21^{\star \star \star}$ & 0.93 & $4.68^{\star *}$ & $4.05^{\star \star *}$ & $6.80^{\star * *}$ & $3.73^{* * *}$ & -0.16 & $5.17^{\star \star \star}$ & $0.10^{\star * *}$ \\
\hline \multicolumn{16}{|c|}{ Conditional variance equation } \\
\hline$\alpha_{0}$ & $7.09^{\star *}$ & 12.99 & $9.19^{*}$ & 2.49 & 0.002 & $18.04^{\star \star \star}$ & 0.05 & $4.43^{*}$ & 6.04 & $1.03^{*}$ & $117.67^{* * *}$ & 1.11 & 7.88 & 64.49 & $0.002^{*}$ \\
\hline$\alpha_{1}$ & 1.07 & $1.25^{\star * *}$ & $0.12^{* * *}$ & $0.61^{* * *}$ & $1.02^{\star \star \star}$ & $0.29^{\star \star \star}$ & $0.63^{\star * *}$ & $1.12^{* * *}$ & 0.93 & $0.25^{\star \star *}$ & $0.41^{* * *}$ & $0.57^{* * *}$ & 0.36 & $0.44^{* *}$ & $0.15^{* *}$ \\
\hline$\alpha_{2}$ & - & $-1.06^{* \star *}$ & - & $-0.56^{* * *}$ & $-0.98^{* \star *}$ & $-0.24^{\star \star *}$ & $-0.63^{\star \star *}$ & $-1.01^{* \star *}$ & $-0.88^{*}$ & $-0.21^{* * *}$ & - & $-0.55^{\star \star \star}$ & - & - & $5.10^{* * *}$ \\
\hline$\beta_{1}$ & $0.44^{\star * *}$ & $0.87^{\star * \star}$ & $0.86^{* * *}$ & $1.22^{* * *}$ & $0.98^{* * *}$ & $0.93^{* * *}$ & $1.11^{* * *}$ & $0.92^{* * *}$ & $1.08^{* * *}$ & $1.02^{* * *}$ & 0.21 & $0.98^{* * *}$ & 0.02 & $0.55^{\star * *}$ & $0.04^{*}$ \\
\hline$\beta_{2}$ & - & - & - & $-0.27^{\star}$ & - & - & $-0.12^{*}$ & - & -0.11 & -0.07 & - & - & 0.60 & - & $0.10^{\star * *}$ \\
\hline LL & -8207 & -10416 & -10081 & -10413 & -3702 & -11568 & -8918 & -9601 & -11323 & -9286 & -10357 & -9822 & -8045 & -10613 & 206 \\
\hline
\end{tabular}


Table 5. Estimation results of model (3), GARCH(p, q), Monday dummy variable excluded, the MEDIUM group

\begin{tabular}{|c|c|c|c|c|c|c|c|c|c|c|c|}
\hline \multicolumn{12}{|c|}{ MEDIUM group } \\
\hline & ALM & AMC & ATM & $\mathrm{COL}$ & LTX & $\mathrm{MCl}$ & MNI & PEK & STX & STF & VST \\
\hline \multicolumn{12}{|c|}{ Conditional mean equation } \\
\hline$b_{2}$ & 0.356 & 0.915 & 1.307 & 0.146 & 2.545 & 1.344 & 4.570 & 1.322 & -1.637 & $2.092^{* *}$ & 0.436 \\
\hline$b_{3}$ & -1.222 & 2.788 & $1.678^{*}$ & -0.723 & 0.246 & 2.157 & 5.974 & 0.843 & $9.686^{\star * \star}$ & -0.127 & -0.013 \\
\hline$b_{4}$ & 0.202 & 3.672 & $1.873^{\star *}$ & -0.022 & -1.214 & 0.025 & 13.307 & 1.051 & -0.607 & $2.837^{\star \star \star}$ & -0.067 \\
\hline$b_{5}$ & 0.293 & 0.984 & 0.182 & -0.166 & -0.887 & 0.825 & 1.569 & 0.772 & 1.870 & 1.392 & 0.755 \\
\hline \multicolumn{12}{|c|}{ Conditional variance equation } \\
\hline$\alpha_{0}$ & $22.65^{\star \star *}$ & $300.9^{\star * *}$ & 1.773 & $46.40^{\star *}$ & $3.142^{*}$ & 1.647 & $17.07^{\star \star \star}$ & $8.132^{\star * \star}$ & 20.584 & 8.344 & 0.102 \\
\hline$\alpha_{1}$ & 0.663 & $0.760^{\star \star}$ & $0.020^{*}$ & $0.488^{\star \star \star}$ & $1.033^{\star \star \star}$ & $0.575^{\star \star \star}$ & $1.002^{\star * *}$ & $0.058^{* * *}$ & $2.405^{\star \star}$ & $0.118^{*}$ & 0.120 \\
\hline$\alpha_{2}$ & -0.529 & - & $0.197^{\star \star}$ & - & $-0.919^{\star \star \star}$ & $-0.548^{\star \star *}$ & $-0.930^{\star \star *}$ & - & - & - & 0.771 \\
\hline$\beta_{1}$ & $0.854^{\star * *}$ & -0.006 & 0.019 & $-0.009^{\star * *}$ & $0.916^{\star \star \star}$ & $1.183^{\star * \star}$ & $0.944^{\star \star *}$ & $-0.009^{* \star}$ & -0.001 & $0.349^{\star \star *}$ & 0.020 \\
\hline$\beta_{2}$ & - & $0.278^{* *}$ & $0.862^{\star * *}$ & 0.203 & - & -0.208 & - & $0.929^{* * *}$ & $0.389^{* *}$ & $0.529^{\star * \star}$ & 0.711 \\
\hline LL & -10551 & -11844 & -9794 & -8995 & -9651 & -12393 & -12368 & -10248 & -11052 & -10560 & -11631 \\
\hline
\end{tabular}


Table 6. Estimation results of model (3), GARCH(p, q), Monday dummy variable excluded, the SMALL group

\begin{tabular}{|c|c|c|c|c|c|c|c|c|}
\hline \multicolumn{9}{|c|}{ SMALL group } \\
\hline & APL & $\mathrm{BDL}$ & EFK & ENP & KMP & MZA & PLA & SME \\
\hline \multicolumn{9}{|c|}{ Conditional mean equation } \\
\hline$b_{2}$ & 0.867 & $-0.104^{*}$ & -0.471 & 0.370 & -0.679 & $2.822^{\star *}$ & -2.956 & -1.948 \\
\hline$b_{3}$ & 1.454 & $-0.170^{\star *}$ & -0.876 & 0.449 & 0.394 & $4.426^{* * *}$ & -1.930 & 0.203 \\
\hline$b_{4}$ & 1.094 & 0.040 & -0.365 & $3.465^{*}$ & 0.906 & 1.736 & $-8.793^{\star \star *}$ & $8.155^{\star \star \star}$ \\
\hline$b_{5}$ & -0.097 & -0.018 & -0.267 & $2.289^{*}$ & 0.678 & 1.725 & $-4.354^{\star *}$ & -1.315 \\
\hline \multicolumn{9}{|c|}{ Conditional variance equation } \\
\hline$\alpha_{0}$ & 4.418 & 0.009 & $0.536^{*}$ & $2.309^{* *}$ & $1.141^{*}$ & 1.806 & $9.578^{* *}$ & 60.21 \\
\hline$\alpha_{1}$ & $2.724^{\star \star \star}$ & $1.906^{\star *}$ & $0.712^{\star *}$ & $0.879^{\star \star *}$ & $0.993^{\star * *}$ & $1.021^{\star \star \star}$ & $1.544^{\star \star *}$ & $0.877^{* *}$ \\
\hline$\alpha_{2}$ & $-0.810^{* *}$ & - & $-0.639^{* *}$ & $-0.855^{\star * *}$ & $-0.847^{* *}$ & - & $-1.063^{\star \star *}$ & 1.814 \\
\hline$\beta_{1}$ & $0.302^{* *}$ & 0.017 & $0.893^{* * *}$ & $0.979^{\star * *}$ & $0.916^{* * *}$ & 0.042 & $0.815^{\star \star \star}$ & 0.029 \\
\hline$\beta_{2}$ & $0.322^{\star * *}$ & $0.478^{\star * *}$ & 0.057 & - & - & $0.639^{\star * \star}$ & - & 0.193 \\
\hline LL & -14474 & -3394 & -10205 & -12904 & -12458 & -12211 & -12636 & -12340 \\
\hline
\end{tabular}

Note: See Table 4 for explanation. 
